\title{
Energetyczne rurociągi wysokoprężne - instalacje po długoletniej eksploatacji
}

\section{High-energy pipelines installations after longterm operated}

\section{Streszczenie}

Długotrwała eksploatacja bloków energetycznych związana jest z pracą w warunkach zmiennych pól naprężeń i temperatury. Materiały konstrukcyjne rurociągów narażone są na oddziaływanie środowiska czynnika roboczego oraz obciążeń mechanicznych. Czynniki te powodują w okresie eksploatacji degradację mikrostruktury, a w rezultacie pogorszenie właściwości materiału. Obciążenia mechaniczne i cieplne skutkują zmiennymi naprężeniami $w$ instalacjach rurociągowych. W dłuższym czasie są one przyczyną zarówno pękania złączy spawanych, jak i awarii elementów kształtowych. Ze względu na parametry pracy szczególną uwagę należy zwrócić na eksploatacje rurociągów wysokoprężnych. Właściwie dobrany i realizowany proces diagnostyczny w istotny sposób wpływa na bezpieczeństwo pracy obiektów energetycznych.

\section{Abstract}

Long-term operation of power units is related to work in conditions of variable stress fields and temperatures. Materials of construction of pipelines are exposed to environments working medium and the action of mechanical loads. These factors cause degradation over the lifetime of microstructure and consequently the deterioration of mechanical properties. Tensions in pipeline installations are results of variable mechanical and thermal load. After a longer period of time they are a reason of stress cracking of welded joints and faults moldings thermal plants and energy facilities of pressure. Due to the parameters of the special care diagnostic diesel pipelines should be covered. A properly run the diagnostic process has a direct impact on safety and reliability of operation of energy facilities.

\section{Wstęp}

Podczas długotrwałej eksploatacji bloków energetycznych materiały konstrukcyjne stosowane w przemyśle energetycznym pracują w warunkach zmiennych pól naprężeń i zmiennej temperatury. Materiały te są narażone na oddziaływanie środowiska gazów i cieczy oraz na działanie obciążeń mechanicznych. Czynniki te powodują w okresie eksploatacji ciągłe zmiany mikrostruktury materiałów i w rezultacie pogorszenie ich właściwości mechanicznych. Efektem wzrostu wartości i koncentracji naprężeń jest pękanie złączy spawanych i awarie elementów kształtowych instalacji cieplnych oraz ciśnieniowych obiektów energetycznych.

Mgr Dariusz Mężyk - Instytut Energetyki, Warszawa.

\section{Główne czynniki awaryjności układów rurociągowych}

Szczególną opieką diagnostyczną należy objąć rurociągi wysokoprężne $z$ uwagi na ich wyjątkowy charakter. Wysoka temperatura, ok. $540^{\circ} \mathrm{C}$ i ciśnienie do $20 \mathrm{MPa}$ powodują, że elementy, z jakich zbudowana jest instalacja, nie zawsze są w stanie przenieść obciążenia i rurociągi mogą ulec zniszczeniu.

Bardzo istotnym problemem występującym podczas eksploatacji urządzeń energetycznych jest wzajemne oddziaływanie układu rurociąg-turbina. Mechanizm wzajemnego oddziaływania tych elementów nie został jednoznacznie określony. $Z$ uwagi na wagę problemu, z którym boryka się większość krajowych elektrowni i elektrociepłowni, prowadzone są wielokierunkowe badania zmierzające do określenia wzajemnego oddziaływania wymienionych elementów bloków energetycznych [1]. 
Na wytężenie materiału elementów ciśnieniowych poza naprężeniami od ciśnienia wewnętrznego i naprężeniami temperaturowymi wpływ mają obciążenia mechaniczne pochodzące od ciężaru rurociągu i zamontowanej na nim armatury oraz pochodzące od ograniczenia swobody dylatacji cieplnej i jakości pracy systemu zamocowań. Ze względu na warunki pracy i związane $z$ nimi obciążenia najistotniejsze znaczenie mają rurociągi pary świeżej, a głównie ich elementy kształtowe (kolana, trójniki, czwórniki, mieszacze pary, zasuwy główne).

Rurociągi pary wtórnie przegrzanej pracują w wysokiej temperaturze, lecz przy znacznie niższym ciśnieniu. $\mathrm{Na}$ rurociągach pary wtórnie przegrzanej znajdują się zawory bezpieczeństwa. Ta część rurociągów pracuje w cyklu okresowym, przez co dochodzi do gwaltownych schłodzeń i wzrostów temperatury co wpływaja na niszczenie niskocyklowe. $Z$ tego powodu tę część rurociągu należy objąć szczególną troską.

\section{Diagnostyka stanu technicznego}

Zakres badań rurociągów pary do wtórnego przegrzewu obejmuje rurociągi o pracy okresowej, elementy kształtowe i odwodnienia. Pozostałe rurociągi należy objąć diagnostyką materiałową zgodnie z obowiązującą instrukcją, a wszędzie tam, gdzie wystąpią zauważalne zmiany materiału lub kształtu, zwiększyć częstotliwość badań [2].

Istotne znaczenie dla monitoringu położeń przestrzennych rurociągów wysokoprężnych mają pomiary geodezyjne prowadzone zarówno w stanach zimnych rurociągów, jak i w stanach pełnego obciążenia cieplnego. Wyniki tych pomiarów są podstawą do określenia rozkładu naprężeń temperaturowych wzdłuż trasy rurociągu ze szczególnym uwzględnieniem elementów kształtowych.
Ważnymi elementami węzła technologicznego pod nazwą główne rurociągi parowe jest zabudowana na nich armatura. Znajduje się ona głównie pod turbiną, ale zabudowana jest na rurociągach i łącznie $z$ nimi powinna być rozpatrywana.

Armaturę tę stanowią zawory szybkozamykające, główne zasuwy parowe i zasuwy obejściowe głównych zasuw parowych. Zawory szybkozamykające są istotnym elementem układu, gdyż one w sytuacjach awaryjnych odcinają dopływ pary do turbiny. Prawie wszystkie układy automatyki zabezpieczeniowej bloku, zarówno cieplnej, technologicznej, jak i elektrycznej w konsekwencji powodują natychmiastowe zamknięcie zaworów szybkozamykających i odcięcie pary od turbiny. Zawory te sterowane są hydraulicznie i są ściśle powiązane $z$ układem oleju regulacyjnego turbiny. W związku $z$ tym, że ich pełna sprawność techniczna ma zasadnicze znaczenie dla bezpieczeństwa eksploatacji bloku energetycznego, powinny one być również objęte systemem diagnostycznym.

Bezpieczeństwo eksploatacji obiektu wiąże się z trwałością, którą można włączyć w zakres ogólnie pojętego wytężenia materiału.

Pojęcie trwałości wymaga określenia:

- czasu granicznego do zniszczenia,

- granicznej liczby cykli do zniszczenia,

- liczby operacji technologicznych,

- innych wielkości mierzalnych.

Wśród czynników wpływających na trwałość elementów urządzeń ciśnieniowych znajdują się czynniki związane z: wykonaniem elementu, montażem, eksploatacją, diagnostyką, naprawami i modernizacją [3].

Aby zapobiec sytuacjom awaryjnym, należy kontrolować pracę systemu zamocowań, sprawdzać geodezyjnie położenie rurociągów $w$ stanach zimnych i gorących oraz prowadzić badania diagnostyczne pozwalające określić stan naprężeń, stopień degradacji struktury materiału, a także przeprowadzić obliczenia oparte na rzeczywistych danych uwzględniających przemieszczenia

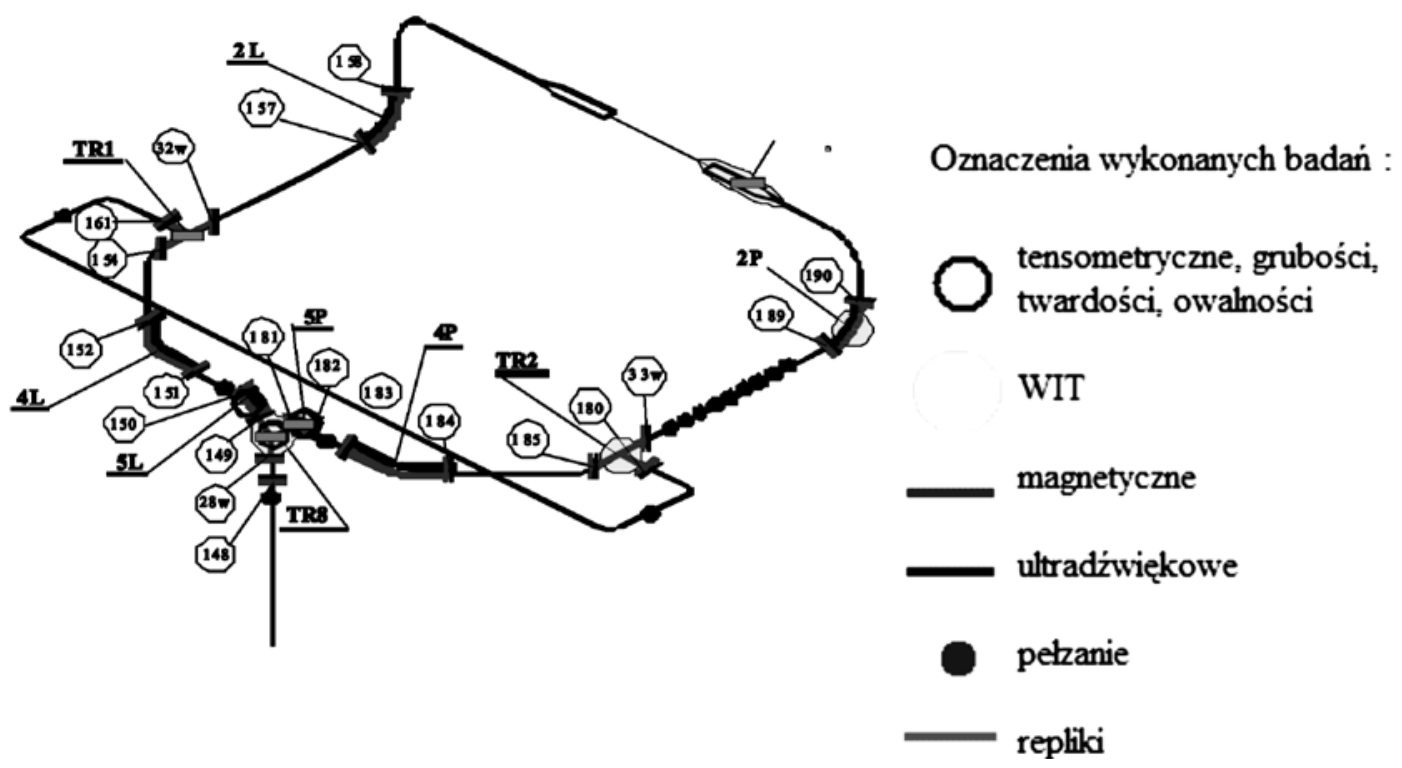

Rys. 1. Przykładowy schemat rozmieszczenia punktów pomiarowych na rurociągach pary

Fig. 1. Model outline of arranging measuring points on pipelines of steam 
dylatacyjne i położenie rurociągu w stanie zimnym i gorącym. Ze względu na zmienność stanu wytężenia materiału obliczenia stopnia wyczerpania trwałości eksploatacyjnej możliwe są w sposób przybliżony. Przeliczenia elastyczności rurociągu prowadzone na podstawie danych zgromadzonych podczas badań rurociągów wraz z armaturą potrafią przybliżyć odpowiedź dotyczącą prawidłowości prowadzonej eksploatacji oraz rozpatrywać symulowane stany przeciążeń i ograniczeń w pracy rurociągów.

\section{Uwarunkowania materiałowe eksploatacji rurociągów wysokoprężnych na przykładzie stali 13HMF (14MoV63)}

W eksploatowanych krajowych obiektach energetycznych od wielu lat w instalacjach rurociągów pary pierwotnej stosowano stal 13HMF (14MoV63) zastępowaną obecnie innymi materiałami, np. P91, P92.

Właściwości mechaniczne elementów rurociągowych wykonanych ze stali 13HMF określane w temperaturze pokojowej, charakteryzują się już nawet po eksploatacji w warunkach pełzania powyżej 100000 godzin niskimi wartościami. Wyniki badań granicy plastyczności czy energii łamania są znacznie niższe niż wymagania minimalne dla stanu wyjściowego tej stali.

Pogorszenie tych właściwości spowodowane jest zmianami struktury stali, do których zalicza się:

- rozpad obszarów bainit/perlit,

- rozwój procesów wydzieleniowych węglików (przemiany węglików, zmiana morfologii - kształtu, wielkości i rozmieszczenia faz wtórnych, zubożenie osnowy w dodatki stopowe).

W stali 13HMF po długotrwałej eksploatacji obserwuje się powstawanie nowych węglików zarówno wewnątrz, jak i na granicach ziaren oraz rozrost już istniejących. Przy założeniu stosunkowo stabilnego poziomu temperatury pracy wzrost naprężeń może przyczynić się do znacznego wzrostu wydzieleń, rozpadu obszarów perlit/bainit, co w konsekwencji prowadzi do nadmiernej utraty trwałości [4].

Długotrwała eksploatacja elementów rurociągowych pracujących w warunkach pełzania powoduje degradację materiału przez zmiany strukturalne, które w konsekwencji prowadzą do obniżenia odporności na pełzanie oraz do przesunięcia temperatury przejścia w stan kruchy w kierunku wyższej temperatury.

Nie powoduje to jednak jednoznacznej konieczności dokonania wymiany takich elementów na nowe. W większości przypadków elementy te mogą pracować znacznie poza obliczeniowy czas pracy, co związane jest $z$ istnieniem trwałości resztkowej.

Wymagane właściwości mechaniczne stali 13HMF oraz część uzyskanych wyników badań kolana w temperaturze otoczenia przedstawiono w tablicy I.

Przeprowadzone badanie składu chemicznego próbek potwierdziło zgodność z wymaganiami PN75/H-84024.

Analizując otrzymane wyniki stwierdzić należy, że:

- właściwości uzyskane podczas statycznej próby rozciągania we wszystkich badanych miejscach potwierdzają zgodność $R_{m}$ i $A_{5} z$ wymaganiami PN74/H-74252 [5],

- umowna granica plastyczności $R_{e 0,2}$ we wszystkich badanych miejscach jest nieznacznie niższa od wymagań PN-74/H-74252,

- energia łamania w temperaturze otoczenia próbek Charpy'ego V pobranych ze wszystkich badanych miejsc kolana jest niska, co jest charakterystyczne dla stali 13HMF po długotrwałej eksploatacji i świadczy o znacznym postępie w zmianach struktury.

Ponadto badania wykazały, że umowna granica plastyczności $R_{0,2 t}$ w temperaturze $500^{\circ} \mathrm{C}$ (zawierająca się w granicach $230 \div 242 \mathrm{MPa}$ ) we wszystkich badanych miejscach jest zgodna z wymaganiami PN-74/H-74252 (wartość normatywna $226 \mathrm{MPa}$ ). Wstępne badanie progu kruchości prowadzone w temperaturze ok. $80^{\circ} \mathrm{C}$ na próbkach pobranych z prostki wskazują, że dla tej stali w tym stanie struktury próg kruchości znajduje się

Tablica I. Wyniki badań właściwości mechanicznych kolana po długotrwałej eksploatacji (13HMF)

Table I. The results of mechanical properties tests of the knee after long-term use (13HMF)

\begin{tabular}{|c|c|c|c|c|c|c|}
\hline \multirow{3}{*}{$\begin{array}{c}\text { Oznaczenie } \\
\text { badanej } \\
\text { próbki }\end{array}$} & \multicolumn{6}{|c|}{ Właściwości mechaniczne stali 13HMF } \\
\hline & \multirow{2}{*}{$\begin{array}{c}\text { Kierunek poboru } \\
\text { próbek }\end{array}$} & \multirow{2}{*}{$\begin{array}{l}\mathrm{R}_{\mathrm{e} 0,2} \\
\mathrm{MPa}\end{array}$} & \multirow{2}{*}{$\begin{array}{l}\mathrm{R}_{\mathrm{m}} \\
\mathrm{MPa}\end{array}$} & \multirow{2}{*}{$\begin{array}{l}\mathrm{A}_{5} \\
\%\end{array}$} & $\mathrm{KCU}_{2}, \mathrm{~J} / \mathrm{cm}^{2}$ & \multirow{2}{*}{$\mathrm{HB}$} \\
\hline & & & & & Wyniki (KV), J & \\
\hline \multirow{2}{*}{$\begin{array}{l}\text { wg PN-74/ } \\
\mathrm{H}-47252\end{array}$} & \multirow{2}{*}{ poprzeczny } & \multirow{2}{*}{$\begin{array}{l}\min \\
355\end{array}$} & \multirow{2}{*}{$490-690$} & \multirow{2}{*}{$\begin{array}{c}\min \\
18\end{array}$} & $\min 60$ & \multirow{2}{*}{$\begin{array}{r}135 \\
-180\end{array}$} \\
\hline & & & & & $48 \mathrm{~J}$ & \\
\hline \multirow[b]{2}{*}{ prostka } & \multirow[b]{2}{*}{ poprzeczny } & \multirow[b]{2}{*}{321} & \multirow[b]{2}{*}{531} & \multirow[b]{2}{*}{26,0} & średnia 22 & \multirow{2}{*}{$\begin{array}{l}155 \\
155 \\
153\end{array}$} \\
\hline & & & & & średnia 18 & \\
\hline \multirow{2}{*}{ „rozciągana” } & \multirow{2}{*}{ poprzeczny } & \multirow{2}{*}{313} & \multirow{2}{*}{524} & \multirow{2}{*}{26,4} & średnia 18 & \multirow{2}{*}{$\begin{array}{l}157 \\
155 \\
157\end{array}$} \\
\hline & & & & & średnia 14,5 & \\
\hline
\end{tabular}


w pobliżu $100^{\circ} \mathrm{C}$. Wyniki badań energii łamania J (próbka

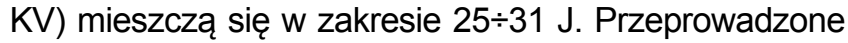
zostały obserwacje zgładów, wszystkie zgłady posiadały strukturę bez widocznych trwałych uszkodzeń pełzaniowych. Analiza uzyskanych wyników badań strukturalnych, a także właściwości mechanicznych prowadzonych w temperaturze otoczenia potwierdza, niekorzystne skłonności stali 13HMF poddanej długotrwałej eksploatacji w warunkach pełzania do niskich energii łamania i niższej granicy plastyczności. Na podstawie analizy wyników, można stwierdzić, że rozpatrywane kolano mogłoby pracować w instalacji rurociągowej ok. $30000 \mathrm{~h}$ do następnych badań diagnostycznych. W innych przypadkach długoletnia praca materiału w warunkach eksploatacji w temperaturach rzędu $540^{\circ} \mathrm{C}$ skutkuje szybciej postępującą degradacją materiału rodzimego oraz występowaniem pęknięć złączy spawanych z reguły w strefie wpływu ciepła.

W zależności od stopnia degradacji materiału stosowane są różne technologie napraw, szlifowanie, napawanie z obróbką cieplną lub wymiana spoiny. Częstą przyczyną uszkodzeń jest poziom naprężeń rzeczywistych w stosunku do wynikających z rzeczywistych wymiarów geometrycznych, głównie grubości ścianki oraz występowania złożonego stanu naprężeń w wyniku oddziaływania momentów gnących i skręcających.

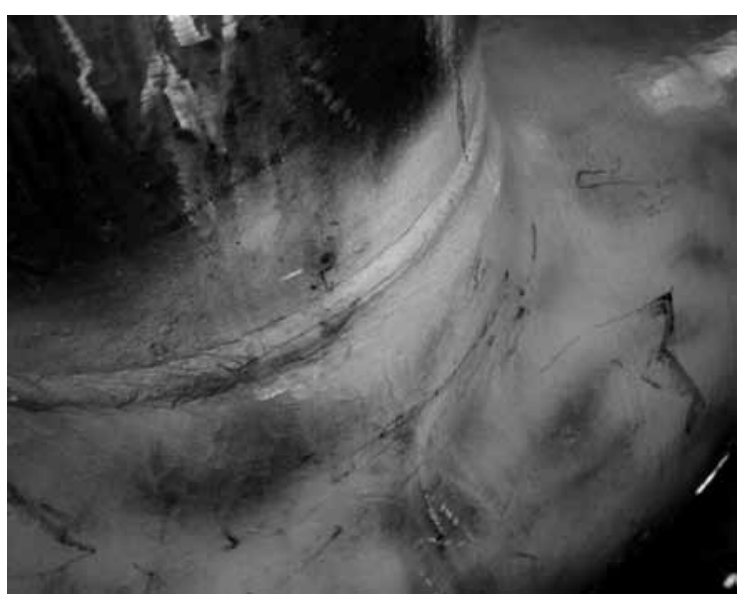

Rys. 2. Pęknięcia na trójniku

Fig. 2. View of cracking on the three-way adapter

\section{Dyskusja awarii rurociągu}

W trakcie długoletniej eksploatacji rurociągów pomimo prowadzonych procesów diagnostycznych mających na celu zapewnienie bezawaryjnej pracy instalacji rurociągowych spotyka się, co jakiś czas sytuacje awaryjne wynikające z przyczyn konstrukcyjnych, eksploatacyjnych i materiałowych.

Poniżej przedstawiony przykład ilustruje zaobserwowaną awarię rurociągu wysokoprężnego - pęknięcie kolana w trakcie eksploatacji (ponad 150000 h) obiektu energetycznego. Przedstawiony przypadek awarii kolana (pęknięcie wzdłużne w wyniku procesów pełzaniowych) jest pierwszym w skali polskich obiektów energetycznych. Pęknięcie wzdłużne jednego z głównych rurociągowych elementów kształtowych pary świeżej stanowi bardzo poważną awarię mogącą pociągnąć za sobą katastrofalne skutki.

Rozkład naprężeń obliczony na podstawie pomiarów dylatacji cieplnej przy założeniu nieprawidłowej pracy zamocowań Z13a i Z12a ujawnia wzrost naprężeń na trójniku widlastym (duże przekroczenie naprężeń dopuszczalnych) oraz wzrost naprężeń na kolanie w rejonie zamocowania Z12a i trójnika przy zamocowaniu Z13a

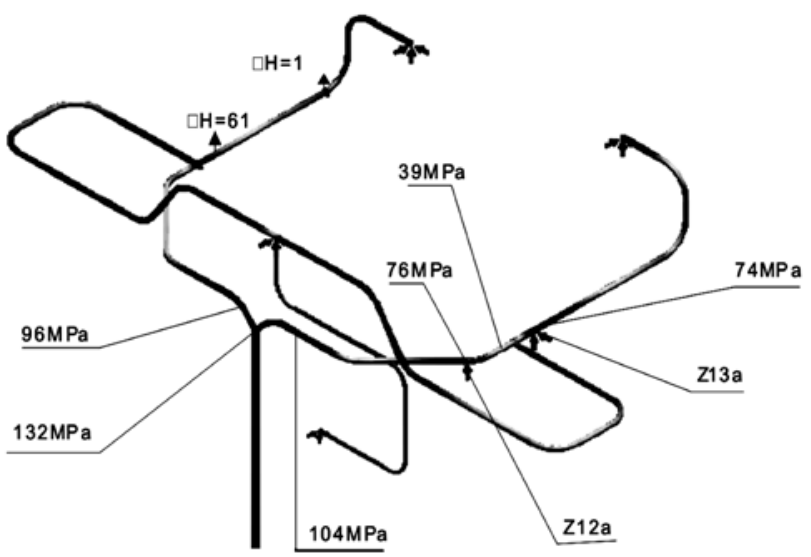

Rys. 3. Rozkład naprężeń przy nieprawidłowej pracy zamocowań (Z12a i Z13a)

Fig. 3. Disintegration of stresses at the invalid work of supports $(Z 12 a$ and Z13a)
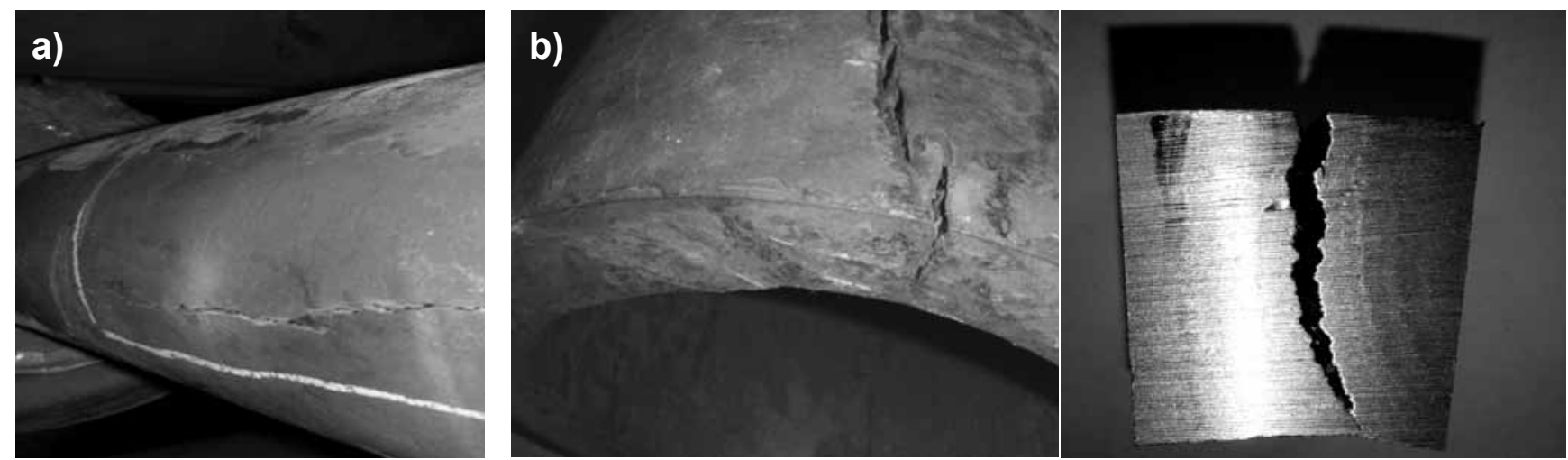

Rys. 4. Uszkodzenie eksploatacyjne rurociągu: a) pęknięcie zlokalizowane na rurociągu, b) fragment materiału pobranego do badań

Fig. 4. Exploitation damage of the pipeline: a) crack located on the pipeline, b) fragment of material picked up for examinations 
Obliczenia prowadzone przy założeniu obciążeń projektowych oraz poprawności działania zamocowań, nie wykazały przekroczeń naprężeń zredukowanych w kolanie, które uległo zniszczeniu. Wytężenie w tym kolanie (stosunek naprężeń od temperatury do naprężeń dopuszczalnych) nie przekraczało wskaźnika 0,5.

Wynik obliczeń w świetle faktu pęknięcia kolana, przy braku wad produkcyjnych, jak i niedopuszczalnych zmian pełzaniowych, wyraźnie wskazuje na dodatkowe inne przyczyny. Stwierdzone szybkie zmiany pełzaniowe $w$ badanym kolanie musiały być spowodowane nieprzewidywalnym lokalnym wzrostem obciążeń.

W rejonie pękniętego kolana stwierdzono niesprawność w pracy układu zamocowań powodującą wzrost naprężeń w materiale rurociągu podczas eksploatacji w zmiennych warunkach cieplnych przez ograniczenie możliwości dylatacyjnych rurociągu.

Badania składu chemicznego próbek potwierdziło zgodnośćze składem materiału 13HMF

Wyniki uzyskane podczas statycznej próby rozciągania w części giętej kolana, po długim czasie eksploatacji, są praktycznie zgodne $z$ wymaganiami $\mathrm{PN}-74 / \mathrm{H}-74252$. Wymienione wyżej właściwości w prostych częściach kolana są znacznie niższe od wymagań PN-74/H-74252. Energia łamania w temperaturze otoczenia próbek Charpy'ego $\vee$ pobranych z odcinków kolana jest bardzo niska, co świadczy o poważnych, niekorzystnych zmianach struktury (umowny próg kruchości - $27 \mathrm{~J}$ ). Badania ultradźwiękowe w całej objętości dostarczonych odcinków kolan z wyłączeniem widocznych pęknięć nie wykryły wzdłużnych ani poprzecznych nieciągłości. Podobnie badania magnetyczno-proszkowe na powierzchni zewnętrznej, a także powierzchni wewnętrznej nie ujawniły nieciągłości powierzchniowych i podpowierzchniowych. Wyjątkiem są okolice pęknięcia głównego, w których wykryto wiele makropęknięć o niewielkiej głębokości. Obserwacje przeprowadzone na zgładach ujawniły strukturę ferrytu z obszarami bainitu. Obszary bainityczne po części skoagulowane. Wewnątrz ziaren ferrytu liczne, w większości drobne, równomiernie rozmieszczone wydzielenia. Na granicach ziaren liczne znacznej wielkości wydzielenia, tworzące łańcuszki. Blisko pęknięcia widoczne liczne nieciągłości mające postaci mikroszczelin.

\section{Wnioski wynikające z zaistniałej awarii}

Stwierdzone szybkie zmiany pełzaniowe w badanym kolanie musiały być spowodowane nieprzewidywalnym lokalnym wzrostem obciążeń. Wzrost naprężeń, a w szczególności momentów skręcających, obciążając uszkodzony element wraz z wyraźnym obniżeniem wskaźników wytrzymałościowych przyczynił się do pęknięcia materiału rurociągu. Opisany przypadek wskazuje również na niebagatelną rolę układu zamocowań dla bezpieczeństwa eksploatacji energetycznych instalacji rurociągowych.

Należy zaznaczyć, że wady materiałów w postaci nieciągłości bądź nieodpowiednich właściwości powstają zarówno w czasie eksploatacji, jak i podczas procesów produkcyjnych. Wady powstające w trakcie eksploatacji to przede wszystkim pęknięcia, uszkodzenia korozyjne i degradacja struktury wskutek procesów zmęczeniowych lub pełzania, szczególnie w przypadku materiałów pracujących w podwyższonej temperaturze. Problem rozwoju uszkodzeń wywołanych procesami pełzaniowymi i zmęczeniowymi mającymi bezpośredni wpływ na żywotność materiału, badany jest obecnie niezależnymi metodami $[4,6 \div 8]$ nieniszczącymi i niszczącymi. Zastosowanie $\mathrm{w}$ procesie diagnostycznym odpowiednich metod badawczych stwarza możliwość formułowania trafnych prognoz czasu bezpiecznej eksploatacji ocenianego obiektu lub elementu.

Tablica II. Wyniki badań współczynników wytrzymałościowych kolana Table II. Results of mechanical factors knees

\begin{tabular}{|c|c|c|c|c|c|c|}
\hline \multirow{2}{*}{ Oznaczenie badanej próbki } & \multicolumn{5}{|c|}{ Właściwości mechaniczne stali 13HMF po eksploatacji } \\
\cline { 2 - 7 } & Kierunek poboru próbek & $\begin{array}{c}\mathrm{R}_{\text {e0,2 }} \\
\mathrm{MPa}\end{array}$ & $\begin{array}{c}\mathrm{R}_{\mathrm{m}} \\
\mathrm{MPa}\end{array}$ & $\begin{array}{c}\mathrm{A}_{5} \\
\%\end{array}$ & $\begin{array}{c}\text { Wyniki (KV) } \\
\mathrm{J}\end{array}$ & $\mathrm{HB}$ \\
\hline prostka od strony pęknięcia & poprzeczny & 370 & 470 & 16 & $\begin{array}{c}8,8,11 \\
\text { średnia } 9\end{array}$ & 162 \\
\hline „rozciągana” & poprzeczny & 319 & 515 & 23 & $\begin{array}{c}34,30,24 \\
\text { średnia 29 }\end{array}$ & 163 \\
\hline
\end{tabular}

Wartości wyjściowe stali 13HMF zawiera tablica I. 


\section{Podsumowanie}

Rozwój nowoczesnych metod badawczych i narzędzi modelowania numerycznego pozwala monitorować postęp degradacji, a w konsekwencji umożliwia przewidywanie okresu żywotności elementu oraz instalacji ciśnieniowych. Wśród metod tych szczególnie użyteczne wydają się metody badań nieniszczących prowadzonych bezpośrednio na obiekcie. Dodatkowo stosuje się procedury oceny z wykorzystaniem maszyn wytrzymałościowych z próbkami wyciętymi z badanych elementów (badania niszczące). Obliczenia MES pozwalają zbudować ogólny model zużycia rozpatrywanych obiektów pracujących powyżej temperatury granicznej z uwzględnieniem czasowego zużycia od pełzania oraz zużycia termozmęczeniowego.

Obecnie do oceny wytrzymałości i niezawodności elementów konstrukcyjnych zawierających pęknięcia wdraża się również narzędzia mechaniki pękania z procedury SINTAP i FITNET [9] oraz metody akumulacji zniszczenia zmęczeniowego.

Prowadzenie badań ma na celu kompleksowa ocenę materiału z zastosowaniem nowoczesnych technik badawczych, prowadzącą do wczesnego wykrycia ewentualnych zmian mikrostruktury i właściwości wytrzymałościowych materiału badanych elementów kryterialnych, a w konsekwencji do oceny stopnia zużycia oraz prognozowania żywotności instalacji energetycznych. Pogorszenie właściwości wytrzymałościowych materiału nie powoduje jednoznacznej konieczności dokonania wymiany eksploatowanych elementów na nowe. W większości przypadków elementy te mogą pracować znacznie poza obliczeniowy czas pracy, co związane jest $z$ istnieniem trwałości resztkowej.

Na bezpieczeństwo i niezawodność eksploatacji obiektów energetycznych najistotniejszy wpływ ma stan wytężenia węzłów kryterialnych, co nierozerwalnie łączy się z prawidłowo prowadzoną polityką diagnostyczną.

Generalnie o stanie rurociągów decyduje stan poszczególnych elementów poddanych największym obciążeniom eksploatacyjnym, tzw. elementów kryterialnych. Dla układu rurociągów wysokoprężnych są to elementy kształtowe, takie jak kolana, trójniki i czwórniki. Dużym obciążeniom podlegają również obszary zmian średnic i grubości ścianek, co ma miejsce na styku rurociąg - trójnik. Są to obszary koncentracji naprężeń mogących powodować pękanie złączy spawanych. W przypadku dalszej długookresowej eksploatacji rurociągów z zachowaniem dotychczasowych parametrów pracy należy uwzględnić wymianę najbardziej wyeksploatowanych elementów kształtowych.

\section{Literatura}

[1] Mężyk D.: Wpływ przebiegu eksploatacji urządzeń ciśnieniowych w energetyce zawodowej na ich bezpieczeństwo i niezawodność pracy, Zagadnienia projektowo-diagnostyczne. Seminarium rozwoju niszczenia materiałów i laserowego modelowania materiałów, Zakopane 2003.

[2] Mężyk D.: Eksploatacja i diagnostyka rurociągów energetycznych, IX Forum Energetyków 2004

[3] Sprawozdanie z badań IEn 6/12.

[4] Kowalewski Z. L.: Degradacja materiałów konstrukcyjnych stymulowana procesem pełzania, Mat. Konf. Seminarium Szkoleniowego „Rozwój zniszczenia materiałów i laserowe modyfikowanie materiałów" 2003.

[5] Polskie normy: PN-75/H-84024, PN-74/H-74252.
[6] Szelążek J.: Postępy w ultradźwiekowych badaniach naprężeń, Prace IPPT mr 4/2001

[7] Płociński T., Manaj W., Spychalski M., Kurzydłowski K. J.: Nieniszczące badania metalograficzne - porównanie technik, Seminarium - Nieniszczące Badania M. 2003.

[8] Kowalewski Z. L., Mackiewicz S., Szelążek J., Deputat J.: Ocena uszkodzenia stali w wyniku pełzania na podstawie badań materiałów, Mat. Konf. XXI Sympozjum Mechaniki Eksperymentalnej Ciała Stałego. 2004.

[9] Neimitz A.: Ocena wytrzymałości elementów konstrukcyjnych zawierających pęknięcia, Wydawnictwo Politechniki Świętokrzyskiej, Kielce 2004. 